\title{
The Effect of Adoption of International Public Sector Accounting Standards on Quality of Financial Reports in Public Sector in Kenya
}

\author{
Robert O. Opanyi (MBA, BBA, CPA) \\ University of Nairobi/Judiciary of Kenya, Kenya
}

doi: 10.19044/esj.2016.v12n28p161 URL:http://dx.doi.org/10.19044/esj.2016.v12n28p161

\begin{abstract}
Quality financial reports plays significant role in accountability of government to their citizens and how it meets its financial management responsibilities. The introduction of IPSAS formed an important part of public sector reforms and followed a global trend in government accounting in response to calls for greater government financial accountability and transparency which is a fundamental principles of democracy. This study focused on effect of adoption of IPSAS on quality of financial reports in meeting the criteria for decision usefulness. The design of this study was the descriptive survey design while the target population was the 19 ministries of the national government in Kenya. Data was collected using secondary means and was analysed using descriptive statistics and t-test for differences. The study indicated enhancement in the quality of characteristics of comparability, relevance, timeliness and faithful representation by adoption of IPSAS while the quality of characteristics of understandability declined. The study also showed no significant difference in items pertaining to transparency and accountability indicating that the goal for government reforms in achieving greater transparency and accountability may not be fully achieved. The study also revealed that adoption of IPSAS is adjudged to have moderate effect on quality of financial reports in public sector in Kenya using a 5 point likert scale. The study concluded that there exist statistically significant difference between old accounting standard-based financial reports and IPSAS-based financial reports in meeting the criteria for decision usefulness as revealed by paired-sample t-test.
\end{abstract}

Keywords: Quality of financial reports, qualitative characteristics, International public sector accounting standards, Public sector 


\section{Introduction}

Public debate on accountability and financial probability in government and government-related entities over the years has attract increasing amount of focus for government to be more involved in responsible governance (Chan, 2008). The quality in financial reports is of key concern not only for final users but for the whole society as it affects economic decisions which may have significant impact. This was most evidenced by a series of corporate failures and financial scandals (Enron, Parmalat, Lehman Brothers, Fortis, AIG etc.) and overall by the economic conditions created by the recent economic recession. As results of increasing demand for greater transparency and accountability in management of public finances, most government all over the world have resolve to reform their government financial management systems and processes. The recent global financial crisis and the severe fiscal constraints being experienced by many government has underscored the need for governments to transparently report all their assets and liabilities (Izedomni et al, 2013). The introduction of IPSAS formed an important part of public sector reforms and is a centrepiece of the global revolution in government accounting and in response to calls for greater government financial accountability and transparency (Chan, 2008; Carlin, 2005). Thus, IPSAS have become de facto international benchmarks for evaluating government accounting practice worldwide (Chan, 2008).

\section{International Public Sector Accounting Standards}

Countries of the world over the years have defined and set the standards of financial reporting in their individual territories. However, globalisation has brought about ever increasing collaboration, international trade and commerce among the countries hence, there is grave need for increased uniformity in the standards guiding financial statements so that such statement would remain comprehensible and convene the same information to users across the world. The need for the development of unified accounting standards has been the primary driver of IPSAS for public sector financial reporting (Heald, 2003).

IPSAS refers to the recommendations made by the IPSASB under the auspices of the IF AC (Delloitte \&Touches, 2013; IPSASB, 2008). IPSAS are norms that govern the recognition, measurement, presentation and disclosure requirements in relation to transactions and events in general purpose financial statements. The development of IPSAS has its origin in the Accounting profession as a way to improve the transparency and accountability of governments and their agencies by improving and standardising financial reporting (Delloitte \& Touches, 2013; Ijeoma, 2014). The IPSASB issues IPSASs dealing with financial reporting under the cash 
basis and the accrual basis of accounting (Kanellos et. al, 2013). It is ideal for all public financial reporting to adopt accrual basis financial reporting. Even so, IPSASB has acknowledged that for many governments, adoption of a cash-basis IPSAS is a more realistic intermediate goal (PWC, 2009). The primary role of the IPSASB is to ensure that published financial statements are uniform in content and in format and communicate precisely what they purport to convey leading to better informed assessments of the resource allocation decisions made by governments, thereby increasing transparency and accountability (Stephen et al, 2012).

\section{Quality of Financial Reporting}

Financial reporting is a communication of financial statements and related information from a business enterprise to third parties (external users). The main objective of financial reporting is to provide high-quality information on reporting entities, which can be used for sound economic decisions making (IASB, 2010). This can positively influence present and potential capital providers and other stakeholders when making economic decisions; (investments, credit decisions, and allocating resources) that may enhance overall capital markets efficiency (IASB, 2008; 2010). It also provides information on management's effectiveness in utilising the resources and running the enterprise. Accountability is beyond the narrow limits of companies' legal responsibility to shareholders. It obviously includes the interest of persons other than existing shareholders (FASB, 1978).

Quality of financial reporting is the precision with which financial reports convey information about the firms operation. Indeed so many definition of financial reporting quality are encountered based on the objectives of each research. For instance; Tang et al, (2008), define financial reporting quality as "the extent to which the financial statements provide true and fair information about the underlying performance and financial position". IASB, (2008), states that "the objective of financial reporting is to provide financial information about the reporting entity that is useful to present and potential equity investors, lenders and other creditors in making decisions in their capacity as capital providers”. AICPA (1970), defines the purpose of financial accounting and financial statements as "the provision of quantitative financial information about a business enterprise useful to the statement users”.

The role however of financial reporting is broader and aims to provide even-handed financial and other information that together with information of other sources facilitates the efficient functioning of capital and other markets and assists the efficient allocation of the scarce resources in the economy, (FASB, 1978). The concept of financial reporting quality is 
therefore broad and includes financial information disclosures and nonfinancial information useful for decision making. Financial reports should meet certain qualitative criteria in order to avoid poor quality and accomplish their purpose. Both IASB and FASB in their Conceptual framework concluded that high quality is achieved by adhering to objective and the qualitative characteristics of financial reporting information (IASB 2008; 2010).Qualitative characteristics are "the attributes that make the financial information useful” (IASB, 2008). However, provision of decision useful information is limited by one pervasive constraint: the costs of reporting information must be justified by its benefits (IASB, 2010). The various qualitative characteristics studied are as follows;

Relevance is the potential that information has of making a difference in the decisions taken by users of that information. "Finance information is capable of making a difference in the decisions if it has predictive value, confirmatory value, or both” (IASB, 2010). Reported information therefore is useful only if it relates to the issues that are prime concern to the users.

To give a faithful representation of economic phenomena, annual reports must be complete, neutral, and free from material errors (IASB, 2010). The phenomenon's to be presented are “economic resources, obligations and the transactions and events that change those resources and obligations", (FASB, 1980).

Understandability; information can be better understood if it is classified, characterised, and presented clearly and concisely. Information with such qualities enables user's comprehension of its exact meaning (IASB, 2008). Information that users do not understand is not useful even if it is relevant.

Comparability is the quality of information that enables users to identify similarities and differences between two sets of economic phenomena. It includes consistency which refers to the use of the same accounting policies and procedures, either from period to period within an entity or in a single period across entities (IASB, 2010).

Timeliness means that information becomes available to decisionmakers before it loses its capacity in influencing decisions. Timeliness refers to the amount of time it takes to make information known to others, and it is related to decision usefulness in general (IASB, 2010).

\section{Relationships between IPSAS and Quality of Financial Reporting}

The fundamental economic function of accounting standards is, to provide agreement about how important commercial transactions are to be implemented. According to Clarke (2009), if accounting reports are not prepared following the standards, then the meaning of comparisons between performance in different time periods and the performance between entities 
are virtually impossible. Barth et al, (2006) suggest that accounting quality could be improved with elimination of alternative accounting methods that are less reflective of firm's performance and are used by managers to manage earning. Overall, evidence on voluntary IFRS adoption and accounting quality is mixed, however there is relatively better accounting quality among the firms that adopt IFRS (Christen send et al. 2008; Ashbaugh \& Pincus, 2001).

By eliminating many international differences in accounting standards, and standardising reporting formats, IFRS eliminate many of the adjustments that analysts historically have made in order to make companies financial information more comparable internationally. IFRS adoption therefore could make it less costly for investors to compare firms across markets and countries (e.g. Armstrong et al, 2007; Covrig et al, 2007). Thus, a common set of accounting standards would solve agency problem in corporate sector, reduce information asymmetries among investors and/or lower estimation risk by increasing comparability between lower and higher quality firms (Bradshw et al, 2004; Daske et al, 2007). Thus, reducing international differences in accounting standards assists to some degree in facilitating international integration of capital markets (Covrig et al, 2007) by removing barriers to cross-breed acquisitions and divestiture, which in theory will reward investors with increased takeover premiums.

Lastly, better accounting standards make reported earnings less noisy and more accurate, hence more "value relevant". (Ashbaugh \&Pincus, 2001; Hope 2003). It would also, make earning easier to forecast and would improve average analyst forecast accuracy. Ball et al, (2000) thought oppositely that managers in low-quality reporting regimes are able to "smooth" reported earnings to meet a variety of objectives, such as reducing the volatility of their own compensation, reducing the volatility of payouts to other stakeholders (notably, employee bonuses and dividends), reducing corporate taxes, and avoiding recognition of losses.

\section{Public Sector in Kenya}

Government accounting refers to a government and governmentrelated entities financial information systems and financial disclosure practices. Its state of development results from the interaction between the supply of and demand for government's financial accountability and transparency (Chan, 2006). Public sector accounting used to be a mere record keeping of budget execution and most government still adhere to cash basis of accounting, and therefore provide minimal disclosures relative to what is expected of the private sector (Bergmann, 2009; IFAC, 2012 policy position 4). Due to the authorization features of public sector budgets, cash budgets have remained in many countries while accrual accounting is 
adopted for financial reporting. Timely, clear and open annual financial statements plays a significant role in the accountability of government to their citizens and how it meets its financial management responsibilities. This communication is an important part of building trust (PWC, 2009; Ijeoma et al, 2014).

According to a report of the GOK (2006) on PEFA public financial performance management report, the quality of GOK financial reporting is poor with lack of timely, clear and open annual financial statements. The report noted that there is concern about the accuracy and consistency of financial data which are submitted to Accountant General and that essential information may be missing from the summarized financial statements or the financial records are too poor to audit. It also noted that audits predominantly comprises transactions, level testing but report identify significant issues. It further noted that there is little evidence of response or follow-up from public accounts committee and the Ministry of national treasury. The same type of errors and mismanagement occurs year after year despite being repeatedly criticized by the Auditor General. Current revelations during public accounts committee hearing on the Auditor General's reports raise issues of financial accountability and transparency.

Currently Kenya is in dare financial situation, with government debt levels sitting at very precarious levels (ICPAK, 2014). The situation is even complicated as government cash reserves are unaccounted for, and remain unknown kept in accounts earning no interest thus idle cash resource as government continue to borrow increasing the public debt sharply. These resources ends up being misappropriated through corrupt practices, which have serious economic consequences to the nation. Moreover, managing expenditure arrears (pending bills) has always posed a problem for the government. Besides being a conduit for incurring irregular public debts, pending bills or payment arrears were used to siphon public resources into private hands (Njeru, 2010). Furthermore, lack of identification of public assets and liabilities in terms of amounts and timing is a fundamental cause of liquidity and solvency problems, which can become full-blown fiscal crises.

Consequently, in effort to promoting accountability and transparency in management of public resources, GOK has made significant steps in enhancing financial reporting quality by; joining ESAAG (which selected IPSAS as the benchmark for public sector accounting); adoption of IPSAS as its public sector accounting framework, promulgation of the constitution of Kenya 2010 and the Public finances management (PFM) Act 2012 which has anchored public finances on the principles of accountability and clear fiscal reporting (http://www.treasury.go.ke). 


\section{Research Problem}

The quality in financial reports is of prime concern not only for the final users but for the whole society as it affects economic decisions that could significantly impact the society as a whole. The recent global financial crisis and the severe fiscal constraints being experienced by many governments has underscored the need for governments to foster greater financial accountability and transparency. Kenya had her share of failed government entities and failure of government to meet its financial management responsibilities in the past which had dramatic consequences such as social unrest.

There are number of studies that have been done on the effects of international accounting standards on quality of financial reports. For example Ball and Plugrath (2012), states that consistent and appropriate use of IPSAS standards provide high-quality for enhanced comparability and analysis. Chan (2006), lends a lot of credence to the increasing importance of international accounting standards particularly to developing countries once they borrow or rely on foreign aid, and would be a useful tool not only to account for these resources but also to compare the use of them between reporting periods. According to Ijeoma (2014), Implementation of IPSAS impact positively on reliability, credibility and integrity of financial reporting and pave way for uniformity in reporting. Kariuki et al, (2013) in their study titled, "Institutional investor's perception on quality of financial reporting in private sector for companies listed on NSE", stated that users of financial reports must understand the contexts in financial statements in order to use them effectively. They argued that entities must first recognise investors and other users of financial reports as customers. They emphasised that financial reports must be current, comprehensive, easy to understand and accurate. The study concluded that investors perceived the financial reports quality interms of qualitative characteristics.

According to Kiugu (2010), Kenya is in grave need to achieve greater accountability through adoption of consistent accounting basis and user friendly financial reporting format which provide access to a reliable source of performance reports and give periodic comparisons and recognises all transactions in transparent manner. According to Hamisi (2012), GOK financial management systems are not providing timely and accurate financial information for statutory reporting and for decision making. The GOK used difference approaches to prepare financial statements to communicate financial results hence they lacked uniformity, reliability and credibility. The long-term fiscal sustainability is the ability of a government to meet its service delivery to its citizen and financial commitments both now and in future. Strong and transparent financial reporting has the potential to improve public sector decision-making and make government 
more accountable to their constituency (Izedomni et al, 2013). The IPSASbased financial reporting framework has been increasingly publicised as successful tools to address the government provision of financial information problem (PWC, 2009; Ijeoma et al, 2014).

Despite the importance of government transparency and accountability as a recurring policy issue, there is limited research on the effect of adoption of IPSAS on quality of financial reporting in the public sector in Kenya. Instead the current researches have focused on usefulness and feasibility of adoption of IPSAS in public sector in Kenya (e.g. Hamisi 2012; Kiugu, 2010; ICPAK, 2014). This motivates this study as there is a gap in knowledge about the effects of adoption of IPSAS on financial reporting quality in public sector in Kenya. This research seeks to answer the question whether adoption of IPSAS has effect on quality of financial reporting in public sector in Kenya.

\section{Research Objectives}

The objective of this study was to ascertain the effect of the adoption of international Public Sector Accounting Standards on quality of financial reports in public sector in Kenya.

\section{Theoretical Frameworks and Literature Review Theoretical Framework}

Globalisation has brought a grave need for increased uniformity in standard guiding financial reports. There is a mixed view as to whether international accounting harmonisation is beneficial for developing countries because it provides better-prepared standards as well as the best quality accounting framework and principles. There is also a view that accounting information produced according to developed countries accounting systems is not relevant to the decision models of less-developed countries (Perera, 1989 cited in Zeghal and Mhedhbi, 2006). This study was guided by three theories that provided theoretical argument on certain motivating and discouraging factors, that necessities country to adopt certain practices and standards.

\section{The Economic network theory}

A combination of individuals, groups or countries interacting to benefit the whole community. Economic networks use the various competitive advantages and resources of each member to increase the production and wealth of all the members. Economic network theory predicts that in addition to network benefits, a product with network effects can be adopted due to its direct benefits (Liebowitz \& Margolis, 1994 cited in Hamisi, 2012). In the case of the IPSAS adoption by a country, the theory 
argues that the direct benefits are represented by both the net economic and net political value of IPSAS over local standards (Barth, 2008). According to this theory economies with high levels of or expected increases in foreign investment and trade are more likely to adopt IPSAS. This theory reveals evidence of regional trends in IPSAS adoption, such that a country is more likely to implement IPSAS if other countries in its geographical region are IPSAS adopters (Hamisi, 2012). Adopting a set of standards like IPSAS can be more appealing to a country if other countries have adopted them as well, in this sense, IPSAS can be a product with "network effects".

\section{The theory of Isomorphism}

The theory of isomorphism defines the "constraining process that forces one unit in a population to resemble other units that face the same set of environmental conditions” (DiMaggio and Powell 1983 cited in Antwi, 2010).This theory in practice implies that, the features of an organisation can be tuned to some extent for the sake of compatibility and uniformity to suit the surrounding environment of organization in question .The theory of Isomorphism can be classified as follows;

Coercive Isomorphism; Stems from political influence and the problem of legitimacy. It takes the shape of a formal or an informal pressure exerted on an organization by other superior organization upon which they depend as well as cultural environment within which an organization operates. The adoption of IPSAS by developing countries to a larger extent is influenced by external factors such as foreign investors, International accounting firms, and international financial organization among others. Internally such force, persuasions or invitations to adopt IPSAS have been influenced by for example ICPAK, NSE and CMA.

Mimetic Isomorphism; Stems from standard responses to uncertainty. The degree of uncertainty is a powerful force that encourages imitation such that an organisation desire to adopt others' practices that are both successful and worthy of adoption (DiMaggio and Powell 1983 cited in Antwi, 2010). As such uncertain in GOK financial system in managing their finances and inability to matching financial assets and liabilities in terms of amounts and timing might have necessitated government to emulate other public entities that are more legitimate and successful.

Normative Isomorphism; is attributable to professionalization which is defined as the collective struggle of individuals of similar calling organising in a professional organisation to promote a cognitive base, diffuse shared orientations and organisational practices, and legitimise their occupational autonomy (DiMaggio and Powell,1983 cited in Antwi,2010). Professional bodies exhibit similar traits to their professional counterparts in that they mimic each other. These professional bodies to a larger degree 
influence greatly their counterparts. Conscious of this, either of these institutions may mimic the other in instances where a certain standard has worked for them In Kenya such accounting professional bodies as ICPAK, and PSASB positively influence each other very much. However, unless a country opens its doors to these institutions, there is little they can do to politicise the adoption process.

\section{Accounting Theory}

Accounting theory is dynamic and is concerned with improving financial accounting and reporting in broad perspective. It is essential that accounting is used according to generally accepted rules to avoid chaos that would occur in the process. The first prerequisite is that accounting should agree or conform to the basic truths according to which our economic system functions; the current economic and business practices and the applicable law as embodied in legislative regulations or common law. Consequently, it is important that uniformity is maintained in accounting and reporting practice (Kiugu, 2010). The continuously increasing scope and complexity of our economics system requires a corresponding process of adaptation in accounting and effective reporting in order that the relevant information regarding economic activities may be recorded (ASB, 2000).

\section{The Determinants of Quality of financial reporting}

The quality of financial statements is affected by many factors among others the incentives of managers and auditors, company characteristics and the quality of accounting standards comprising GAAP. Two very potential company characteristics affecting quality are industry affiliation and company size (Bowrin, 2008). When it comes to the industry affiliation, banking industry seems to have higher quality concerning financial statements (Bowrin, 2008). Moreover, company size is widely proved to be closely related to timeliness and consequently, to the quality of financial reporting (Owusu-Ansah, 2000). This is due to the fact that larger companies are commonly audited by big audit firms which have more experience and resources (Ashton et al., 1989).

Also, it has been stated that the quality of financial statements is significantly affected by the quantity of information which in this context refers to the amount of financial analyst. In case that the company is followed by number of analysts the quantity of information influences strongly the quality of financial statements. This also indicates a small earnings surprise. By having increased quantity and quality of financial information, the stock prices can actually adjust more quickly (Chan et al, 1997). Shkurti \& Naqellari (2010), also state that third parties lack of demand for financial information is one reason for low quality financial 
statements and continue that lack of professional experts and poor best practice incentives supported by authorities can lead to an absence of high quality data.

According to Jensen \& Meckling (1976), the Presence of agency costs gives rise to a demand for monitoring, and the information and firm's financial statements provide may be used to mitigate agency costs. Highly leveraged firms have higher agency costs and thus a greater demand for monitoring. Therefore, reporting quality vary with a firm's capital structure (Leftwich et al., 1981). If the financial information provided in the firm's annual report is complementary to the monitoring information debt providers use, thus more leveraged firms provides financial information of higher quality.

Moreover, corporate governance and financial information quality have been conducted in the past and the subject is widely debated. Klai \& Omri (2011) researched the characteristics of the board and the ownership and noted that power of families and foreigners decrease the quality of financial statements, but companies facing control from financial institutions or state have better quality disclosures. Since the state and institutional investors are present on the boards, they have the possibility to guarantee the quality of reporting and the monitoring of management. On the other hand, the power of families affects the quality of reporting indicating that they want to protect their wealth and do decisions which are based on their own personal goals (Klai \&Omari, 2011).

The effect of international and national accounting standards should also be taken into account when considering the quality of financial statements. According to Latridis (2010) the adoption of IFRS standards leads to higher quality of financial information for example due to more timely loss recognition and reduced earnings management. Although Barth et al., (2008) also highlight the importance of IAS standards for better quality financial information. They argue that there are two reasons which might worsen the positive impact of accounting standards. Firstly, they state that IAS could be to some extent of lower quality than national standards e.g. when standards reduce management discretion resulting in accounting measurements which do not reflect performance and financial position as well as domestic standards. Secondly, Barth et al, (2008) noted that quality improvements arising from IAS could be offset by the characteristics of financial reporting system other than standards.

The increased complexity of accounting and auditing standards and requirements has raised concerns about the auditors and companies' ability to meet the requirements while shortening their reporting lags, for instance as a result of SEC's new filling requirements in 2003 (Krishnan \& Yang, 2009). SEC's introduction of a shorter filing time for the companies and the demand 
for a greater quality of financial reporting e.g. due to Sarbanes-Oxley Act of 2012 have resulted in the reporting challenges. However, the possible conflicts between faster reporting and quality of financial statements seem not to appear, since the long audit reporting lags were not in association with lower quality of accruals (Krishnan \& Yang, 2009).

\section{Empirical Review}

Financial reports quality cannot be observed directly and depends on the perceptions of individual users, which might be context-specific. Over the years, various types of measurement methods have been developed to assess and evaluate the quality of financial reporting (Verrechia, 2001). The methods most often used in previous research are capital market-based researches in accounting and studies on earnings management and earnings quality (Kothari, 2001; Armstrong et al, 2010; Mohammad, 2011). These approaches examine the decision usefulness of the information given in financial reports by examining the relations between accounting-based and market-based attributes. A main advantage of such quality assessment methods is that the quality metrics are generally reliable. Quality proxies can be assessed and replicated by using publicly available financial information from annual reports and stock markets (Healy \& Wahlen, 1999). A major drawback of these methods however, is their lack of validity as they provide only partial and indirect proxies for decision usefulness. In addition, nonfinancial information is excluded, which means that a truly comprehensive assessment is not made (Healy \& Wahlen, 1999). With regards to value relevance models, the stock market may not be as efficient as assumed. As a consequence, stock prices do not always represent the market value of firms accurately or fail to react timely to unexpected firm disclosure (Kothari, 2001).

Another group of quality measurement methods focuses on the quality of specific financial and non-financial information elements disclosed in annual reports. For example, studies that examine the association between the decisions usefulness of financial reporting information and the use of fair value (Hirst et al, 2004), between the quality of internal control and the risk of disclosing information and auditor's reports. However, such methods do not by definition give a comprehensive assessment of financial reporting quality.

Finally, there are some studies that aim to give a comprehensive measurement of decision usefulness by assessing the quality of the different dimensions of reporting information simultaneously, including both financial and non-financial information (e.g. Jonas \& Blanchet 2000; McDaniel et al, 2002). Have developed questions on distinct qualitative characteristics in order to assess information quality. Although such research has shown that 
qualitative characteristics can indeed be operationalized, the measures used are based on the older frameworks of the FASB (1980) and the IASB (1989) rather than the more recent CF IASB (2010) and certain inconsistencies with the CF may result. Lastly, some of the operational definitions used are incomplete and focus solely on relevance and Faithful representation (e.g. McDaniel et al., 2002). The enhancing qualitative characteristics of understandability, comparability and timeliness are usually perceived to be less important than fundamental qualitative characteristics. Even so, it does remain important to include such items in the analysis, so as to arrive at a truly comprehensive assessment.

\section{Research Methodology Sample and Data}

The design of the study was the descriptive survey design while the population of interest for the purpose of this study will be all the 19 ministries of GOK. There was no sampling since the population was not too large and it can be covered as whole. The use of the ministries is due to availability and reliability of data because all the ministries are required by law and government regulation to files annual reports with the National treasury. The study utilised secondary data based on the annual financial statements and reports of all the 19 ministries in the sample, prepared using the two different accounting standards; the old standards-based report and IPSAS-based reports. The document analysis was used because is the convenient, quick and effective way to collect the data for doing research.

\section{Data Analysis}

Data collected was checked for completeness, it was then summarised, coded and tabulated with assistance of statistical package (SPSS version 20). Statistical tools that was used to analysis the data include the descriptive statistics which was used to describe the study variables, paired-sample t-test to test the differences if it exists between old accounting standards and whether there are any significant differences in quality scores. Data containing the results was then presented using frequency tables to ensure the information gathered is clearly understood.

\section{Analytical models}

A key issue that impact directly to the nature of research in financial reporting is the measurements of quality of financial reports. A useful categorization of measurement tools is provided by Van Beast et al, (2009), who identified four broad and not restrictive categories; accrual models, value relevance models, specific element of financial reports and methods that operationalize the qualitative characteristics. This study used the 
methods that operationalize the qualitative characteristics that aim to assess the quality of different aspects and dimensions of financial and non-financial information of financial reports in order to determine their usefulness. This is achieved through the use of indexes or questionnaire created to capture the qualities of quantitative characteristics. This study developed and tested a comprehensive multiple-item quality index which is conceptually based on CF (IASB, 2010) and which is based on items used in previous research (e.g. Jones \& Blachet, 2000; McDaniel et al, 2002; Daske \& Gebhart, 2006; Gafarov, 2009). $Y=\beta o+\beta_{1} X_{1}+\beta_{2} X_{2}+\beta_{3} X_{3}+\beta_{4} X_{4}+\beta_{5} X_{5}+\varepsilon$

Where: $Y=$ Financial Reports Quality Index

$\beta_{0}=$ Constant or intercept $\quad \beta=$ Regression model coefficient (Parameters),

$\mathrm{X}_{1}=$ Relevance, $\quad \mathrm{X}_{2}=$ Faithful Representation, $\quad \mathrm{X}_{3}=$ Understandability, $\mathrm{X}_{4}=$ Comparability,$\quad \mathrm{X}_{5}=$ Timeliness $\quad \varepsilon=$ Error term

\section{Data Analysis, Results and Discussion Assessment of Financial Reports Quality based on 25-items Index}

This study assessed the quality of the financial reports using 25-items in different steps. First, it used a content analysis to score all items, using their pre-defined measurement scales (Appendix I). The indexes for qualitative characteristics for each individual financial report were computed. To compute these indices the scores of the individual items per qualitative characteristics were aggregated and we're subsequently divided by the maximum number of items in the relevant category. The study also, used descriptive statistics to compute average disclosure scores on the individual measurement items and the differences between the mean scores on IPSAS-based reports and Old standards-based reports.

On the characteristics of relevance(R) the study revealed that the items pertaining to information on forward-looking information in prediction of future development (R1), information on future opportunities (R2), cash flow information (R5) and information on financial structure (R9) in IPSAS-based reports scored on average higher than Old standards-based reports. However, IPSAS-based reports scored almost the same with the old standards-based reports showing no significant difference in items pertaining to fair value information (R3), corporate social responsibility (R4), offbalance activities (R6), going concern (R7) and intangible assets (R8). Therefore, Results shows that cash-based IPSAS standard still disclose information based on historical cost accounting which is regarded to be less relevant compared to fair value which give more relevant information. 
Moreover, both reports gave incomplete and less detail on the assets, liability, contingencies and commitments.

On faithful representation, results revealed that item (F1) scored highly, but the other measurement items of faithful representation showed no significant difference from reports based on both standards. Financial reports can never be completely free from bias, since economic phenomena presented in financial reports are frequently measured under conditions of uncertainty. Many estimates and assumptions are included in the financial reports. However, if valid explanations are provided for the assumptions and estimations made, they could represent the economic phenomena without bias. The auditor's reports add value to financial reporting information by providing reasonable assurance about the degree to which the financial reports represent economic phenomena faithfully. Reports based on both standard disclosed limited information on negative development of an entity. Neutrality is about objectivity presentation of events rather than focusing solely on the positive events that occurs without mentioning negative events. Information on management bonus is not disclosed as sub section in financial reports based on both standards rather all allowances are aggregated for all employees including directors.

On understandability, old standards-based reports scored on average highly than IPSAS-based reports, this could be so because old standardsbased are simpler to account for and understand. IPSAS-based reports scored slightly more on disclosure of entities mission and strategy and on wellorganization of reports. However, there was limited presence of tabular or graphic formats in IPSAS-based reports which may improve understandability by clarifying relationships and ensuring conciseness. IPSAS-based reports contained technical jargon which affects the understandability with lack of explanation in glossary of terms this affect understandability of the information.

On comparability, IPSAS-based reports were on average higher than the corresponding scores of old standards-based reports. IPSAS-based reports scored highly on disclosure of accounting policy and estimates changes. New information, rules or regulations generally causes entities to change their estimates, judgement and accounting policies. There was limited disclosure of benchmark education information and ratio and index numbers in IPSAS-based reports although slightly better than in old standards-based reports. Comparability not only refers to consistency but comparability between different entities or even benchmark education to a superior entity in an industry. The accounting policies, structure of financial reports or notes to accounts and other events are of special importance in assessing comparability. In addition, ratios and index numbers can be useful when comparing entities performance. 
On timeliness, the results of the study revealed that IPSAS-based reports on average scored slightly higher than Old standards-based reports. This could be due to IPSAS requirements shortening their reporting lags. Although old standards-based were simpler in nature and easy to prepare they were not prepared and filled on time.

\section{Assessment of Financial Reports Quality Differences}

In this section the study sought to determine if difference exists and whether that difference in quality scores was significant. The differences between the means scores of IPSAS-based reports and Old standards-based reports and the significant of the differences were computed. Table 2 and 3 shows the results of the paired-sample t-test for all measurement items and the total quality level.

\begin{tabular}{|c|c|c|c|c|c|c|c|}
\hline \multirow[b]{2}{*}{ Items } & \multirow[b]{2}{*}{$\mathrm{N}$} & \multicolumn{2}{|c|}{$\begin{array}{l}\text { IPSAS-Based } \\
\text { Reports }\end{array}$} & \multicolumn{2}{|c|}{$\begin{array}{c}\text { Old Standard-Based } \\
\text { Reports }\end{array}$} & \multicolumn{2}{|c|}{ Differences } \\
\hline & & Mean & $\begin{array}{c}\text { Std. } \\
\text { Deviation }\end{array}$ & Mean & $\begin{array}{c}\text { Std. } \\
\text { Deviation }\end{array}$ & Mean & $\begin{array}{c}\text { Std. } \\
\text { Deviation }\end{array}$ \\
\hline $\mathrm{R} 1$ & 19 & 3.7367 & 0.9912 & 2.0000 & 1.0541 & 1.7368 & -0.0629 \\
\hline $\mathrm{R} 2$ & 19 & 3.5789 & 1.0174 & 2.0526 & 1.0260 & 1.5263 & -0.0086 \\
\hline R3 & 19 & 2.1579 & 0.9582 & 2.0526 & 1.0260 & 0.1053 & -0.0678 \\
\hline $\mathrm{R} 4$ & 19 & 2.1053 & 1.1970 & 1.3684 & 0.8307 & 0.7369 & 0.3663 \\
\hline R5 & 19 & 3.1579 & 1.3443 & 1.6316 & 1.1648 & 1.5263 & 0.1795 \\
\hline R6 & 19 & 2.8421 & 0.8983 & 2.0526 & 1.0260 & 0.7895 & -0.1276 \\
\hline R7 & 19 & 1.5789 & 1.1698 & 1.1579 & 0.3746 & 0.4210 & 0.7952 \\
\hline R8 & 19 & 3.2105 & 0.9177 & 2.3684 & 1.1161 & 0.8421 & -0.1984 \\
\hline R9 & 19 & 3.2632 & 1.1945 & 2.0000 & 1.0541 & 1.2632 & 0.1404 \\
\hline $\mathrm{F} 1$ & 19 & 2.8947 & 0.8753 & 1.8947 & 1.1002 & 1.0000 & -0.2250 \\
\hline F2 & 19 & 2.9474 & 0.7799 & 2.0000 & 1.0541 & 0.9474 & -0.2742 \\
\hline F3 & 19 & 1.7368 & 1.2402 & 1.3158 & 0.8201 & 0.4210 & 0.4201 \\
\hline F4 & 19 & 3.1053 & 0.8753 & 2.2632 & 0.8719 & 0.8421 & 0.0034 \\
\hline F5 & 19 & 2.1053 & 0.9941 & 1.9474 & 1.0788 & 0.1579 & -0.0846 \\
\hline $\mathrm{U} 1$ & 19 & 2.2632 & 0.9335 & 1.5789 & 1.1698 & 0.6843 & -0.2363 \\
\hline U2 & 19 & 2.7895 & 0.9763 & 4.0000 & 1.3333 & -1.2105 & -0.3570 \\
\hline U3 & 19 & 2.8421 & 0.8983 & 4.5263 & 1.1723 & -1.6842 & -0.2740 \\
\hline $\mathrm{U} 4$ & 19 & 2.2105 & 0.9177 & 3.9474 & 1.4327 & -1.7369 & -0.5150 \\
\hline U5 & 19 & 2.1579 & 0.9582 & 1.8947 & 1.1002 & 0.2632 & -0.1421 \\
\hline C1 & 19 & 3.9474 & 1.4327 & 1.9474 & 1.0788 & 2.0000 & 0.3539 \\
\hline $\mathrm{C} 2$ & 19 & 4.3684 & 1.2115 & 2.6316 & 1.0651 & 1.7368 & 0.1464 \\
\hline C3 & 19 & 3.4737 & 1.1239 & 2.3684 & 0.9551 & 1.1053 & 0.1688 \\
\hline C4 & 19 & 2.3158 & 1.0029 & 2.2632 & 0.9335 & 0.0526 & 0.0695 \\
\hline C5 & 19 & 2.2632 & 1.0457 & 2.0526 & 1.0260 & 0.2106 & 0.0198 \\
\hline $\mathrm{T} 1$ & 19 & 3.2632 & 1.3267 & 2.9474 & 0.7799 & 0.3158 & 0.5469 \\
\hline Valid N (listwise) & 19 & 2.8126 & 1.0512 & 2.2505 & 1.0258 & 0.5621 & 0.0255 \\
\hline
\end{tabular}

Table 1: Assessment of Financial Reports Quality based on 25-items Index 
At an aggregate level, it can be seen that the average total quality disclosure scores is 2.81 and 2.25 for IPSAS-based reports and Old standards-based reports respectively. This results shows that IPSAS standard has moderate effect on quality of financial reports based on 5 point likert scale. Therefore IPSAS standards enhance quality of financial reports more than Old standards although the differences in improvement in quality is moderate.

\begin{tabular}{|c|c|c|c|c|c|}
\hline \multicolumn{2}{|c|}{} & Mean & $\mathrm{N}$ & Std. Deviation & $\begin{array}{c}\text { Std. Error } \\
\text { Mean }\end{array}$ \\
\hline \multirow{2}{*}{ Pair 1} & IPSAS-Based Reports & 2.8132 & 25 & .71063 & .14213 \\
\cline { 2 - 6 } & OLD STD-Based Reports & 2.2504 & 25 & .82315 & .16463 \\
\hline
\end{tabular}

Table 2: Paired Samples Test; Financial reports quality Differences

\begin{tabular}{|c|c|c|c|c|c|c|c|c|c|}
\hline & \multicolumn{5}{|c|}{ Paired Differences } & \multirow[t]{3}{*}{$\mathrm{t}$} & \multirow[t]{3}{*}{$\mathrm{df}$} & \multirow{3}{*}{$\begin{array}{c}\text { Sig. } \\
\text { (2-tailed) }\end{array}$} \\
\hline & & \multirow[t]{2}{*}{ Mean } & \multirow[t]{2}{*}{$\begin{array}{c}\text { Std. } \\
\text { Deviation }\end{array}$} & \multirow[t]{2}{*}{$\begin{array}{c}\text { Std. } \\
\text { Error } \\
\text { Mean }\end{array}$} & \multicolumn{2}{|c|}{$\begin{array}{c}95 \% \\
\text { Confidence } \\
\text { Interval of the } \\
\text { Difference }\end{array}$} & & & \\
\hline & & & & & Lower & Upper & & & \\
\hline $\begin{array}{c}\text { Pair } \\
1\end{array}$ & $\begin{array}{c}\text { IPSAS -Based } \\
\text { Reports } \\
\text { Old Std-Based } \\
\text { Reports }\end{array}$ & .5628 & .9690 & 1938 & .1628 & .9628 & 2.904 & 24 & .008 \\
\hline
\end{tabular}

Table 3: Paired Samples Test; Significant differences in quality scores

The results provide useful descriptive statistics of the financial reports based on two standards, including the mean and standard deviation, as well as the actual results from the paired t-test. The results shows there is a mean difference between the two reports of 0.5628 with standard deviation of 0.9690 , a standard errors of the mean of 0.1938 and $95 \%$ confidences interval of 0.1628 to 0.9628 and degree of freedom of 24 and the statistical significance (2-tailed $\mathrm{p}$-value) of the paired t-test (P-value $(|\mathrm{T}|>|\mathrm{t}|)$ under critical value of the mean difference of 0.000 . The results showed that the $t-$ statistics is equal to 2.904 and the p-value is 0.008 . Since the p-value is very low $0.008<0.05$, thus the study conclude that there is strong evidence of a mean increase in quality of IPSAS-based financial reports against old standards-based financial reports.

\section{Summary, Conclusions and Recommendations Summary}

The aim of this descriptive study was to ascertain the effect of adoption of IPSAS on quality of financial reports in public sector in Kenya. The study assessed the extent to which quality differences can be said to exist between old standards-based and IPSAS-based financial reports in meeting the decision usefulness specified by the CF of the IASB (2010). In 
order to study this, a 25-items quality index, which was conceptually based on CF, was used.

As the paired-sample t-test showed, IPSAS-based reports scored on average higher on the quality index than Old standards-based reports did. These results suggest that the total quality of the IPSAS-based financial reports outperformed the old standards-based reports. Also, as compared with IPSAS financial reports, old standards-based reports disclosed limited information on topics such as going concern, corporate social responsibility, corporate governance, fair value information and disclosure of director's bonuses and assets. On the other hand, old standards-based reports perform better with respect to the lack of technical jargon and complexity thus scores highly on characteristics of understandability. Essentially, the results indicate that IPSAS financial reports are at least more comprehensive and integrated and more decision useful for these reasons.

The analysis indicate mixed results as statistically the IPSAS-based reports has significant difference from old standards-based reports with characteristics of comparability, timeliness, faithful representation, relevance scoring higher compared to standards based reports while characteristics of understandability declined in quality. On the other hand the results indicate that the goal of new public financial management reforms for greater transparency and accountability may not be fully achieved as IPSAS-based reports scored almost the same with the old standards-based reports showing no significant differences in items pertaining to corporate governance, going concern, fair value information, disclosure of directors bonuses, negative development of an entity, disclosure of assets and corporate social responsibility. This results is in conformity with the literature as it indicates the importance of financial reporting in promotion of financial transparency and accountability. Therefore accounting takes on a greater social role as accountability requirements in a country that requires higher standards of ethical behaviour.

IPSAS standard are vital in developing and building detailed quality financial reports as showed by the results IPSAS-based reports outperformed the old standards-based reports which is conformity with the literature. Furthermore, each country possess unique and identical traits that motivates them to adopt a particular accounting standards. Kenya could have been motivated by macro-economic and political factors. The results conform to this argument as characteristics of comparability scored high indicating that GOK adopted the standards due to its advocacy for standardisation of financial reporting which creates the possibility of comparability of financial statements and even the consolidation of financial statements particularly for the two levels of government (national and county government). Uniformity in the reporting requirements for the entire government stimulates the 
contribution within the different accountability chains. This is further confirmed by the need of uniformity within the regional block having seen neighbouring countries (Rwanda, Uganda and Tanzania) successful adopting and implementing the IPSAS standards. Kenya being in forefront to ensure successful East Africa community block establishment could regard uniformity in reporting critical for the regional block economic development.

\section{Conclusion}

The results of the study indicates enhancement in the quality of characteristics of comparability, relevance, timeliness and faithfull representation by adoption of IPSAS while the quality of characteristics of understandability declined. Even though there is significant difference in quality of financial reports, the cash-based IPSAS adopted by Kenya cannot fully assure transparency and accountability. Cash-basis IPSAS differ fundamentally from the approach under accrual-basis IPSAS where payment is not the decisive factor but rather a fundamental change to the ownership of the risks and rewards. As well as timing differences, cash-basis is on one simpler to account for and understand but on the other hand gives much less details on key issues such as the debt owed by an entity, the level of assets held or the potential future liabilities in terms of provisions that it has.

From the evidence gathered by this study, we conclude that there is a statistically significant difference between the IPSAS-based reports and Old standards-based reports. Therefore the adoption of IPSAS is adjudged to have moderate effect on the quality of financial reports in public sector in Kenya. This results suggests that financial reports are at least more comprehensive and integrated as results of adoption of IPSAS. However, it should be recognised that only accrual-basis IPSAS achieves full transparency, accountability and provides the information needed for decision-making. Introducing accrual basis IPSAS can be very difficult and often a step too far for GOK, depending on the current position and resources, however it must still be recognised as the ultimate goal.

One limitation of this study is that the study is limited to a period of one financial year that may raise uncertainty about generalisation of the results. IPSAS is still a new concept in Kenya having been promulgated, thus using more reasonable periods for at least 3-5 years may enhance the quality of the results. Another limitation relate to issues of subjectivity that may arise due to one individual rater evaluating and interpreting annual reports. Reliability could be enhanced by more independent raters assessing and interpreting the information in annual reports. 


\section{Recommendations}

Based on the finding, the study recommends the following; The GOK should move towards gradually applying accrual basis IPSAS standards instead of the current adopted cash basis IPSAS. It is only appropriate to accrue assets and liabilities to the extent that benefits exceed costs. However, strong accrual should be done cautiously after serious and careful analysis of validity and the benefits expected from the reforms taking into account the conditions, the priorities and local characteristics of Kenya. Also the new public financial management reforms should improve more public sector financial management such as modifying budget laws and financial mechanisms for public entities by granting more autonomy and discretion for spending units so that the spending unit managers can manage their own units, improve more medium term and performance budgeting and medium term allocations so as to provide information of outputs, outcomes, influences for accounting because accrual based accounting recognises shortterm assets and liabilities and long-term ones such as future obligations and effects of transactions. Thus by growing financial data on past transactions and events to enable government financial accounting to provide a reality check against the more speculative future forecasts and plans in budgeting.

\section{References:}

1. AICPA, (1970), APB Statement No 4, Basic concepts and accounting principles underlying financial statements of business enterprises, (cited in Rosenfield, 2006).

2. Armstrong, C., Barth, M. E., Jagolinzer, A., \& Riedl, E. J. (2010). Market reaction to the adoption of IFRS in Europe. The Accounting Review, 85(1), 31-61.

3. Ashbaugh, H. \& Pincus, M. (2001). 'Domestic accounting standards, international accounting standards, and the predictability of earnings'. Journal of Accounting Research, 39:417-434.

4. Ashton, Robert H., Graul, Paul R. and Newton, James D. (1989): "Audit delay and timeliness of corporate reporting", Contemporary accounting research, vol.5, no.2.

5. Ball, I., Pflugrath, G. (2012) Government Accounting: Making Enron look good. World Economics Journal. 13 (1).

6. Ball, R., Kothari, S., and Robin, A. (2000) the effect of international institutional factors on properties of accounting earnings, Journal of Accounting and Economics, 29.

7. Barth, M.E., Landsman, W.R. and Lang, M.H. (2008) International accounting standards and accounting quality, Journal of Accounting Research 46(3),. 
8. Beast Van F., Bream G. and Boelens S., (2009), Quality of financial reporting; measuring qualitative characteristics, working paper, Nice.

9. Bergmann, A. (Ed.). (2009). Public sector financial management, $1^{\text {st }}$ Edition ed.): Pearson education limited.

10. Bowrin, Anthony R. (2008): "International accounting standards and financial reporting quality in Trinidad and Tobago", Business, finance and economics in emerging economies, vol.3, no.1.

11. Bradshaw, M., Bushee, B \& Miller, O. (2004), Accounting choice, home bias, and U.S. investment in Non-U.S. Firms, Journal of Accounting Research 42, 795-841.

12. Carlin, T.M. (2005), 'Debating the Impact of Accrual Accounting and Reporting in the Public Sector', Financial Accountability \& Management, Vol. 21, No. 3.

13. Chan, I.J. (2008), International Public Sector Accounting Standards: Conceptual and Institutional Issues.

14. Chan, J. L. (2006). IPSAS and Government Accounting Reform in Developing Countries.

15. Chen, Carl R., Lin, James Wuh and Sauer, David A. (1997): "Earnings announcements, quality and quantity of information and stock price changes", Journal of financial research, vol. XX, no.4.

16. Clarke, P., (2009), Interpretation of financial statements, Chartered association of certified Accountants (ACCA).

17. Daske, H., Hail, L., Leuz, C. \& Verdi, R. (2007). Adopting a Label: Heterogeneity in the economic consequences of IFRS adoptions, Working paper, University of Pennsylvania and University of Chicago.

18. Delloite (2013), International Public Sector Accounting Standards in your pocket, 2013 Edition.

19. DiMaggio P.J. and Powell W. (1983). The Iron Cage Revisited. 1983 Cited in Antwi K.G. 2010.

20. Ernst and Young, (2014), International Public Sector Accounting Standards Outlook EAS.

21. FASB, (1978), Concept No 1, Objectives of Financial Reporting by Business Enterprises.

22. FASB (2010), Conceptual framework for financial reporting (Chapter 3: Qualitative characteristics of useful financial information). Statement of Financial Accounting Concepts No. 8, Norwalk, CT.

23. Gassen, J., \& Schwedler, K. (2010). The decision usefulness of financial accounting measurement concepts: Evidence from an online survey of professional investors and their advisors. European Accounting Review, 19(3), 495-509. 
24. GOK (2006) PEFA Public financial performance management reports.

25. Hamisi K.S. (2012), The factors affecting the implementation of IPSAS in Kenya, Unpublished MBA project, University of Nairobi.

26. Heald D. (2003), the global revolution in government accounting, Symposium in Public Money \& Management, Vol. 23, No. 1.11.

27. Healy, P., \& Wahlen, J. (1999). A review of the earnings management literature and its implications for standard settings. Accounting Horizons, 13(4), 365-383.

28. Hirst, D., Hopkins, P., \& Wahlen, J. (2004). Fair values, income measurement, and bank analysts' risk and valuation judgments. The Accounting Review, 79(2), 453-472.

29. Hope, O. (2003) Disclosure practices, enforcement of accounting standards, and analysts' forecast accuracy: An international study, Journal of Accounting Research, 41(2).

30. Hung, M. and Subramanyam, K. R. (2007) Financial statement effects of adopting international accounting standards: The case of Germany, Review of Accounting Studies, 12: 623-657.

31. ICPAK, (2014) Public Finance Building blocks for Devolution; ISBN No.978-9966-1808-0-3.

32. IFAC (2012) Public Sector Financial Management Transparency and Accountability; the use of IPSAS, IFAC Policy position 4.

33. Ijeoma N.B, (2014) The Impact of IPSAS on Reliability, Credibility and Integrity of Financial Reporting in State Government Administration in Nigeria. Journal of Technology Enhancements \& Emerging Engineering Research Vol 2, Issue 3, 2014.

34. IASB, (2008). Exposure draft on an improved conceptual framework for financial reporting: The objective of financial reporting and qualitative characteristics of decision-useful financial reporting information. London.

35. IASB, (2010), the conceptual framework for financial reporting. http://eifrs.iasb.org/eifrs/bnstandards/en/framework.pdf.

36. IPSASB, (2008), Handbook of International Public Sector Accounting Pronouncements (New York: IFAC, 2008).

37. Izedonmi F. and Ibadin P. (2013) IPSAS Framework, Regulatory Agencies and Standrads setting procedures, European journal of business and management ISSN 2222-2839 Vol 5, No 6.

38. Jonas, G., \& Blanchet, J. (2000). Assessing quality of financial reporting. Accounting Horizons, 14(3), 353-363.

39. Kanellos, T., Evangelos P., Dimitrios B. (2013), Concept, regulators \& institutional issues of IPSAS; A Critical review, European journal of business \& social sciences Vol 2, No 1, PP43-54. 
40. Kariuki G. and Jagongo A. (2013) Institutional Investors’ Perceptions on Quality of Financial Reporting in Kenya. International Journal of Humanities and Social Science Vol. 3 No. 21 Special Issue - Dec 2013.

41. Kiugu F. (2010), a survey of perception on the adoption of international public sector accounting standards by local authorities in Kenya, Unpublished MBA project, University of Nairobi.

42. Klai, Nesrine and Omri, Abdelwahed (2011): "Corporate governance and financial reporting quality: The case of tunisian firms", International business research, vol.4, no.1.

43. Kothari, S. P. (2001). Capital markets research in accounting. Journal of Accounting and Economics, 31(1-3), 105-231.

44. Krishnan, Jayanthi and Yang, Joon S. (2009): "Recent trends in audit report and earnings announcement lags", Accounting Horizons, Vol.23, No.3.

45. Latridis, G., (2010): “International financial reporting standards and the quality of financial statement information", International review of financial analysis, 19.

46. Leftwich, R.W., Watts, R. L., and Zimmerman, J.L., (1981). Voluntary Corporate Disclosure: The Case of Interim Reporting. Journal of Accounting Research 18: 50-77.

47. McDaniel L., Martin R., and Maines L., (2002), Evaluating financial reporting quality; the effects of financial experts vs. financial literacy. The accounting review, 77, 139-167.

48. Mohammady, A. (2011). Earnings quality constructs and measures. Working Paper. Retrieved from http://ssrn.com/abstract=1678461.

49. Ndungu B. (2014), Enhancing your brand through Integrated Reporting, Fire Award Report 2014.

50. Njeru K. (2010) Public finance under new constitution, Constitution working paper No 5, ISBN NO 978-029-04-1.

51. Owusu-Ansah, Stephen (2000) “Timeliness of corporate financial reporting in emerging capital markets: Empirical evidence from the Zimbabwe stock exchange”, Accounting and business research, vol. 30, no.3.

52. Price Waterhouse Cooper (2009); Introduction to International Public Sector Accounting Standards.

53. Shkurti, Rezarta and Naqellari, Julian (2010): “Quality of financial and accounting information in Albania as perceived by the practical accountants", Journal of accounting and finance, issue 47.

54. Stephen E., Mercy N., and Wynne A. (2012) Annual Financial Reporting by Governments- existing and practices in sub-Saharan Africa, African Capacity Foundation. 
55. Tang Q, Chen H, Zhijun L, (2008), financial reporting quality and investor protection: a global investigation, working paper.

56. Verrechia, R. E. (2001). Essays on disclosure. Journal of Accounting and Economics, 32(1-3), 97-180.

57. Zeghal D. and Mhedhbi K., (2006), An analysis of the factors affecting the adoption of International stanadrds by developing countries. Published by University of Illinois 2006.

58. http://www.ifac.org/public-sector/projects/public- sector-conceptualframework

59. http://www.kenyalaw.org:8181/exist/kenyalex/actview.xql?actid=CA P. $412 \mathrm{C}$

60. http://www.kenyalaw.org:8181/exist/kenyalex/actview.xql?actid=cons $\mathrm{t} 2010$

61. http://www.treasury.go.ke/index.php/component/docman/cat_view/14 5-psasb-new-reporting-standards-andformats?orderby=dmdate_published.

\section{APPENDIX I: MEASUREMENT ITEMS}

Overview of the measurement items used to operationalize the Qualitative characteristics. (Including the Measurement Scales)

\begin{tabular}{|c|c|c|c|}
\hline \multicolumn{4}{|c|}{ Relevance } \\
\hline $\begin{array}{l}\text { Quest } \\
\text { ion } \\
\text { No. }\end{array}$ & Question & Operationalization & Concept \\
\hline R1 & $\begin{array}{l}\text { To what extent does the } \\
\text { presence of the forward- } \\
\text { looking statement help } \\
\text { forming expectations and } \\
\text { predictions concerning the } \\
\text { future of the company? }\end{array}$ & $\begin{array}{l}\text { 1= No forward-looking information } \\
2=\text { Forward-looking information not an apart } \\
\text { subsection } \\
3=\text { Apart subsection } \\
4=\text { Extensive predictions } \\
5=\text { Extensive predictions useful for making } \\
\text { expectation }\end{array}$ & $\begin{array}{l}\text { Predictive } \\
\text { value }\end{array}$ \\
\hline $\mathrm{R} 2$ & $\begin{array}{l}\text { To what extent does the } \\
\text { presence of non-financial } \\
\text { information in terms of } \\
\text { business opportunities and } \\
\text { risks complement the } \\
\text { financial information? }\end{array}$ & $\begin{array}{l}\text { 1= No non-financial information } \\
\text { 2= Limited non-financial information, not very } \\
\text { useful for forming expectations } \\
3=\text { Sufficient useful non-financial information } \\
4=\text { Relatively much useful non- financial } \\
\text { information, helpful for developing } \\
\text { expectations } \\
5=\text { Very extensive non-financial information } \\
\text { presents additional information which helps } \\
\text { developing expectations }\end{array}$ & $\begin{array}{l}\text { Predictive } \\
\text { value }\end{array}$ \\
\hline R3 & $\begin{array}{l}\text { To what extent does the } \\
\text { entity uses fair value as } \\
\text { measurement basis } \\
\text { instead of historical cost? }\end{array}$ & $\begin{array}{l}1=\text { Only Historical cost } \\
2=\text { Most Historical cost } \\
3=\text { Balance fair value and Historical cost } \\
4=\text { Most Fair value } \\
5=\text { Only fair value }\end{array}$ & $\begin{array}{l}\text { Predictive } \\
\text { value }\end{array}$ \\
\hline R4. & $\begin{array}{l}\text { To what extent does the } \\
\text { annual report contain } \\
\text { information on CSR? }\end{array}$ & $\begin{array}{l}1=\text { No information on CSR } \\
2=\text { Limited information on CSR } \\
3=\text { Sufficient information on CSR }\end{array}$ & $\begin{array}{l}\text { Predictive } \\
\text { value }\end{array}$ \\
\hline
\end{tabular}




\begin{tabular}{|c|c|c|c|}
\hline & & $\begin{array}{l}4=\text { Very much information on CSR } \\
5=\text { Very extensive information on CSR }\end{array}$ & \\
\hline R5. & $\begin{array}{l}\text { To what extent does the } \\
\text { annual report contain an } \\
\text { analysis concerning cash } \\
\text { flows? }\end{array}$ & $\begin{array}{l}\text { 1= No analysis } \\
2=\text { Limited analysis } \\
3=\text { Sufficient analysis } \\
4 \quad=\quad \text { Very much analysis } \\
5=\text { Very extensive analysis }\end{array}$ & $\begin{array}{l}\text { Predictive } \\
\text { value }\end{array}$ \\
\hline R6. & $\begin{array}{l}\text { To what extent are the } \\
\text { "off-balance" activities } \\
\text { disclosed? }\end{array}$ & $\begin{array}{l}1=\text { No disclosure } \\
2=\text { Limited disclosure } \\
3=\text { Sufficient disclosure } \\
4=\text { Very much disclosure } \\
5=\text { Very extensive disclosure }\end{array}$ & $\begin{array}{l}\text { Predictive } \\
\text { value }\end{array}$ \\
\hline R7 & $\begin{array}{l}\text { To what extent does the } \\
\text { annual report contain } \\
\text { information concerning } \\
\text { the companies' going } \\
\text { concern? }\end{array}$ & $\begin{array}{l}1=\text { No information concerning going concern } \\
2=\text { Limited information concerning going } \\
\text { concern } \\
3=\text { Sufficient information concerning going } \\
\text { concern } \\
4=\text { Very much information concerning going } \\
\text { concern } \\
5=\text { Very extensive information concerning } \\
\text { going concern }\end{array}$ & $\begin{array}{l}\text { Predictive } \\
\text { value }\end{array}$ \\
\hline R8 & $\begin{array}{l}\text { To what extent are the } \\
\text { intangible assets disclosed }\end{array}$ & $\begin{array}{l}1=\text { No disclosure } \\
2=\text { Limited disclosure } \\
3=\text { Sufficient disclosure } \\
4=\text { Very much disclosure } \\
5=\text { Very extensive disclosure }\end{array}$ & $\begin{array}{l}\text { Predictive } \\
\text { and } \\
\text { confirmatory } \\
\text { value }\end{array}$ \\
\hline R9 & $\begin{array}{l}\text { To what extent is the } \\
\text { financial } \\
\text { disclosed? }\end{array}$ & $\begin{array}{l}1=\text { No disclosure } \\
2=\text { Limited disclosure } \\
3=\text { Sufficient disclosure } \\
4=\text { Very much disclosure } \\
5=\text { Very extensive disclosure }\end{array}$ & $\begin{array}{l}\text { Predictive } \\
\text { and } \\
\text { confirmatory } \\
\text { value }\end{array}$ \\
\hline \multicolumn{4}{|c|}{ Faithful Representation } \\
\hline$\overline{\mathrm{F} 1}$ & $\begin{array}{l}\text { To what extent are valid } \\
\text { arguments provided to } \\
\text { support the decision for } \\
\text { certain assumptions and } \\
\text { estimates in annual } \\
\text { report? }\end{array}$ & $\begin{array}{l}\text { 1= No valid arguments } \\
2=\text { Limited valid arguments } \\
3=\text { Sufficient valid arguments } \\
4=\text { Very much valid arguments } \\
5 \text { = Very extensive valid arguments }\end{array}$ & Verifiability \\
\hline F2 & $\begin{array}{l}\text { Which type of auditors' } \\
\text { report is included in the } \\
\text { annual report? }\end{array}$ & $\begin{array}{l}1=\text { Adverse opinion } \\
2=\text { Disclaimer of opinion } \\
3=\text { Qualified opinion } \\
4=\text { Unqualified opinion: financial figures } \\
5=\text { Unqualified opinion: financial figures }+ \\
\text { internal control }\end{array}$ & $\begin{array}{l}\text { Free from } \\
\text { material } \\
\text { error, } \\
\text { verification, } \\
\text { neutrality, } \\
\text { and } \\
\text { completenes } \\
\text { s }\end{array}$ \\
\hline F3 & $\begin{array}{l}\text { To what extent does the } \\
\text { company provide } \\
\text { information on corporate } \\
\text { governance? }\end{array}$ & $\begin{array}{l}1=\text { No description of corporate } \\
\text { governance } \\
2=\text { Limited description of corporate } \\
\text { governance } \\
3=\text { Sufficient description of corporate } \\
\text { governance } \\
4=\text { Very much description of corporate } \\
\text { governance } \\
5=\text { Very extensive description of corporate }\end{array}$ & $\begin{array}{l}\text { Completenes } \\
\text { s, } \\
\text { verifiability, } \\
\text { and free } \\
\text { from } \\
\text { material } \\
\text { error }\end{array}$ \\
\hline
\end{tabular}




\begin{tabular}{|c|c|c|c|}
\hline & & governance & \\
\hline F4 & $\begin{array}{l}\text { To what extent does the } \\
\text { annual report contain } \\
\text { disclosure related to both } \\
\text { positive and negative } \\
\text { contingencies? }\end{array}$ & $\begin{array}{l}1=\text { No disclosure } \\
2=\text { Limited disclosure } \\
3=\text { Sufficient disclosure } \\
4=\text { Very much disclosure } \\
5=\text { Very extensive disclosure }\end{array}$ & $\begin{array}{l}\text { Completenes } \\
\text { s and } \\
\text { verifiability }\end{array}$ \\
\hline F5 & $\begin{array}{l}\text { To what extent does the } \\
\text { annual report contain } \\
\text { information concerning } \\
\text { bonuses of the board of } \\
\text { directors? }\end{array}$ & $\begin{array}{l}1=\text { No information concerning bonuses } \\
2=\text { Limited information concerning bonuses } \\
3=\text { Sufficient information concerning bonuses } \\
4=\text { Very much information concerning bonuses } \\
5=\text { Very extensive information } \\
\text { concerning bonuses }\end{array}$ & Neutrality \\
\hline \multicolumn{4}{|c|}{ Understandability } \\
\hline U1 & $\begin{array}{l}\text { To what extent is the } \\
\text { annual report presented in } \\
\text { a well-organized manner? }\end{array}$ & $\begin{array}{l}1=\text { Very bad presentation } \\
2=\text { Bad presentation } \\
3=\text { Poor presentation } \\
4=\text { Good presentation } \\
5=\text { Very good presentation }\end{array}$ & $\begin{array}{l}\text { Understanda } \\
\text { bility }\end{array}$ \\
\hline $\mathrm{U} 2$ & $\begin{array}{l}\text { To what extent does the } \\
\text { presence of graphs and } \\
\text { tables clarify the } \\
\text { presented information? }\end{array}$ & $\begin{array}{l}1=\text { No graphs } \\
2=1-5 \text { graphs } \\
3=6-10 \text { graphs } \\
4=11-15 \text { graphs } \\
5=>15 \text { graphs }\end{array}$ & $\begin{array}{l}\text { Understanda } \\
\text { bility }\end{array}$ \\
\hline U3 & $\begin{array}{l}\text { To what extent does the } \\
\text { annual report contain } \\
\text { technical jargon in the } \\
\text { perception of the } \\
\text { researcher? }\end{array}$ & $\begin{array}{l}1=\text { Very much jargon } \\
2=\text { Much jargon } \\
3=\text { Moderate use of jargon } \\
4=\text { Limited use of jargon } \\
5=\text { No/hardly any jargon }\end{array}$ & $\begin{array}{l}\text { Understanda } \\
\text { bility }\end{array}$ \\
\hline $\mathrm{U} 4$ & $\begin{array}{l}\text { What is the size of the } \\
\text { glossary? }\end{array}$ & $\begin{array}{l}1=\text { No glossary } \\
2=\text { Less than } 1 \text { page } \\
3=\text { Approximately } 1 \text { page } \\
4=1-2 \text { pages } \\
5=>2 \text { pages }\end{array}$ & $\begin{array}{l}\text { Understanda } \\
\text { bility }\end{array}$ \\
\hline U5 & $\begin{array}{l}\text { To what extent does the } \\
\text { annual report contain } \\
\text { information concerning } \\
\text { mission and strategy? }\end{array}$ & $\begin{array}{l}1=\text { No information concerning mission and } \\
\text { strategy } \\
2=\text { Limited information concerning mission } \\
\text { and strategy } \\
3=\text { Sufficient information concerning mission } \\
\text { and strategy } \\
4=\text { Very much information concerning mission } \\
\text { and strategy } \\
5=\text { Very extensive information concerning } \\
\text { mission and strategy }\end{array}$ & $\begin{array}{l}\text { Understanda } \\
\text { bility }\end{array}$ \\
\hline \multicolumn{4}{|c|}{ Comparability } \\
\hline $\mathrm{C} 1$ & $\begin{array}{l}\text { To what extent are } \\
\text { changes in accounting } \\
\text { policies disclosed? }\end{array}$ & $\begin{array}{l}1=\text { No disclosure } \\
2=\text { Limited disclosure } \\
3=\text { Sufficient disclosure } \\
4=\text { Very much disclosure } \\
5=\text { Very extensive disclosure }\end{array}$ & Consistency \\
\hline $\mathrm{C} 2$ & $\begin{array}{l}\text { To what extent are } \\
\text { changes in accounting } \\
\text { estimates disclosed? }\end{array}$ & $\begin{array}{l}1=\text { No disclosure } \\
2=\text { Limited disclosure } \\
3=\text { Sufficient disclosure } \\
4=\text { Very much disclosure } \\
5=\text { Very extensive disclosure }\end{array}$ & Consistency \\
\hline $\mathrm{C} 3$ & To what extent does the & $1=$ No comparison & Consistency \\
\hline
\end{tabular}




\begin{tabular}{|c|c|c|c|}
\hline & $\begin{array}{lr}\text { annual report contain } \\
\text { information concerning } \\
\text { comparison and effects of } \\
\begin{array}{l}\text { accounting } \\
\text { changes? }\end{array} \\
\end{array}$ & $\begin{array}{l}2=\text { Actual adjustments }(1 \text { year }) \\
3=2 \text { years } \\
4=3 \text { years } \\
5=4 \text { or more years }\end{array}$ & \\
\hline C4 & $\begin{array}{l}\text { To what extent does the } \\
\text { company present financial } \\
\text { index numbers and ratios } \\
\text { in the annual report? }\end{array}$ & $\begin{array}{l}1=\text { No ratios } \\
2=1-5 \text { ratios } \\
3=6-10 \text { ratios } \\
4=11-15 \text { ratios } \\
5=>15 \text { ratios }\end{array}$ & $\begin{array}{l}\text { Comparabilit } \\
\text { y }\end{array}$ \\
\hline C5 & $\begin{array}{l}\text { To what extent does the } \\
\text { annual report contain } \\
\text { benchmark information } \\
\text { concerning competitors? }\end{array}$ & $\begin{array}{l}1=\text { No benchmark information } \\
2=\text { Limited benchmark information } \\
3=\text { Sufficient benchmark information } \\
4=\text { Very much benchmark information } \\
5=\text { Very extensive benchmark } \\
\text { information }\end{array}$ & Consistency \\
\hline \multicolumn{4}{|c|}{ Timeliness } \\
\hline T1 & $\begin{array}{l}\text { How many days did it } \\
\text { take for the auditor to sign } \\
\text { the auditors' report after } \\
\text { book-year end? }\end{array}$ & $\begin{array}{l}\text { Natural logarithm of amount of days } \\
1=1-1.99 \\
2=2-2.99 \\
3=3-3.99 \\
4=4-4.99 \\
5=5-5.99\end{array}$ & Timeliness \\
\hline
\end{tabular}

